2 - ORIGINAL ARTICLE

Models, Biological

\title{
Studies of distribution and recurrence of Helicobacter spp. gastric mucosa of dogs after triple therapy ${ }^{1}$
}

\author{
Estudos da distribuição e recorrência do Helicobacter spp. na mucosa gástrica de cães após \\ terapia tríplice
}

\begin{abstract}
Thiago Pires Anacleto ${ }^{\mathrm{I}}$, Luiz Roberto Lopes ${ }^{\mathrm{II}}$, Nelson Adami Andreollo ${ }^{\mathrm{III}}$, Walter Octaviano Bernis Filho ${ }^{\mathrm{IV}}$, Maria Cristina Costa Resckv, Adriano Macedo ${ }^{\mathrm{VI}}$

${ }^{1}$ Research performed at the Faculty of Veterinary Medicine, FEPI, Itajuba-MG, Faculty of Veterinary Medicine, UNIFENAS, Alfenas-MG and Laboratory of Enzymology and Experimental Carcinogenesis of the Experimental Surgery and Medicine Division, Faculty of Medical Sciences, UNICAMP, Campinas-SP, Brazil. Part of thesis Master degree. Tutor: Prof. Dr. Luiz Roberto Lopes.

${ }^{\mathrm{I}}$ Fellow Master degree in Surgery, Faculty of Medical Sciences, UNICAMP, Campinas-SP, Brazil. Conception and design.

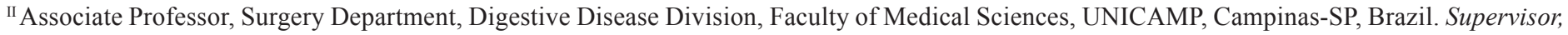
conception and design.

III Full Professor, Digestive Disease Division, Department of Surgery, Faculty of Medical Sciences, UNICAMP, Campinas - SP, Brazil. CoSupervisor, conception and design.

IV Assistant Professor, Surgery Department, Faculty of Veterinary Medicine, UNIFENAS, Alfenas-MG, Brazil. Acquisition, analysis and interpretation of data.

${ }^{\mathrm{v}}$ Assistant Professor, Anatomy Department, Faculty of Veterinary Medicine, UNIFENAS, Alfenas-MG, Brazil. Acquisition, analysis and interpretation of data.

${ }^{\mathrm{VI}}$ Assistant Professor, Pathology Department, Faculty of Medicine, UNIFENAS, Alfenas-MG, Brazil. Acquisition of data, analysis and interpretation and histopathogical studies.
\end{abstract}

\begin{abstract}
Purpose: To analyze the triple antimicrobial therapy in positive Helicobacter spp. dogs and to investigate recurrence. Methods: A total of 20 dogs underwent endoscopy followed by gastric biopsy using the rapid urease test and histopathology stained with Giemsa. Ten animals were treated with triple therapy recommended for humans and divided into control and experimental group. The control group was kept in isolation while the experimental group was placed in contact with positive animals during 60 days. Results: The prevalence of infection in animals in this experiment was $100 \%$, and more frequent in the fundus and the gastric body. Therapy for 7 days using clarithromycin, amoxicillin and lansoprazole was effective in $100 \%$ of the animals. Recurrence of the infection in $80 \%$ of dogs in the experimental group, while the control group remained eradicated after 60 days. Conclusion: Crowded environments associated with close contact with dogs infected with helicobacter are a determinant for transmission of Helicobacter spp. between canines.
\end{abstract}

Key works: Helicobacter infections. Endoscopy. Gastric Mucosa. Dogs.

\section{RESUMO}

Objetivo: Avaliar a eficácia da terapia tríplice em cães naturalmente infectados pelo Helicobacter spp. e investigar a recorrência da infecção pelo contato com animais infectados. Métodos: Foram utilizados 20 cães, submetidos à endoscopia digestiva alta seguida de biopsia gástrica usando teste rápido da urease e histopatologia corada pelo Giemsa. Dez animais foram tratados com terapia tríplice preconizada para humanos e divididos em grupo controle e experimental. O grupo controle foi mantido em isolamento enquanto que o grupo experimento foi colocado em contato com os animais positivos durante 60 dias. Resultados: A prevalência da infecção nos animais deste experimento foi de $100 \%$, e mais frequente no fundo e corpo gástrico. A terapia durante 7 dias empregando claritromicina, amoxicilina e lansoprazol foi eficaz em $100 \%$ dos animais. Houve recorrência da infecção em $80 \%$ dos cães do grupo experimental, enquanto que o grupo controle manteve-se erradicado após 60 dias. Conclusão: Ambientes aglomerados associado a íntimo contato com cães infectados por helicobactérias é fator determinante para transmissão do Helicobacter spp. entre caninos. Descritores: Infecção por Helicobacter . Endoscopia. Mucosa Gástrica. Cães. 


\section{Introduction}

The Helicobacter gender was defined by ribossomic RNA composition studies of sequential hybridation of the bacteria DNA. Belonging to the VI gram-negative bacteria superfamily, they are microaerophyle bacteria, curved and spiral, of smooth surface, measuring close to $0,1 \mathrm{um}$ to $0,5 \mathrm{um}$ wide by $3 \mathrm{um}$ length having round extremities followed by flagellated tufts ${ }^{1}$.

After stating the relation between the presence of the Helicobacter pylori bacteria and the gastritis genesis, gastric and duodenal ulcer in human by Marshall and Warren ${ }^{2}$, other species of spiral bacteria were identified and described in many animal species including dogs $\mathrm{s}^{3}$.

More than half of the world population is infected by Helicobacter pylori. It happens in about $40 \%$ in developed countries, $70 \%$ in developing countries and in low socioeconomical communities with low hygiene it is higher ${ }^{4,5}$.

In Brazil, recent studies using the urease test, histopathology and sorology on street dogs show $80 \%$ to $100 \%$ Helicobacter spp. prevalence, found with higher frequency at the fundus and gastric body ${ }^{6,7}$.

The gastric Helicobacter commonly found in dogs are Helicobacter bizzozeroni, Helicobacter felis, Helicobacter heilmannii and Helicobacter salomonis ${ }^{8}$.

The Helicobacter spp. transmission mechanisms are not clear yet. The fecal-oral and oral-oral ways are the most probable ${ }^{4,9}$

Epidemiologic studies suggest that poor hygiene conditions, including contaminated food and water can be determinant factors to the transmission among humans and animals ${ }^{10}$.

The current therapy scheme indicated to the Helicobacter pylori eradication in humans is the triple therapy, which includes an acid secretion inhibitor in combination with two antibiotics ${ }^{11,12}$.

Metronidazole, clarithromycin, amoxicillin, tetracycline and furazolidone are the most used antimicrobial drugs ${ }^{11}$. According to the II Brazilian Consense about Helicobacter pylori, the therapy associated with clarithromycin, amoxicillin and a proton bomb inhibitor, is an efficient therapy, being indicated as first option for bacteria eradication ${ }^{12}$.

The bacteria reccurrence seems to occur in a discreet parcel of patients ${ }^{13,14}$. Scientific informations related to reinfection are still restricted and show that the levels are higher in developing countries ${ }^{13}$.

The understanding of the transmission ways seem to be fundamental to establish strategies to an efficient treatment and specially to control helicobacteriosis in humans and animals.

The objective of this research is to analyze, the Helicobacter spp. prevalence in the distinct stomach regions in the canine specie, the efficacy of the clarithromycin, amoxicillin and lansoprazole association to eradicate the bacteria in dogs and determine if there is infection reccurrence by direct contact with infected dogs.

\section{Methods}

This research had previous permission of the UNICAMP Ethics Committee of Animal Use, Biology Institute (protocol $\mathrm{n}^{\mathrm{o}}$ 1801-1).

We included in the study 20 street dogs, adults, within close to $20 \mathrm{~kg}$, naturally infected with Helicobacter spp. confirmed diagnosis by the fast urease test and histology. The animals were maintained at the Veterinary Medicine Hospital Kennel from the Itajuba University Center - UNIVERSITAS, vermifugated and vaccined according to veterinary medical protocol.

To perform the high digestive endoscopy, all animals received associated $0.04 \mathrm{mg} / \mathrm{kg}$ atropine sulfate, $0.004 \mathrm{mg} / \mathrm{kg}$ fentanil citrate, $1 \mathrm{mg} / \mathrm{kg}$ acepromazine acetate by intramuscular injection as preanesthesic medication. The propofol was used at a $3 \mathrm{mg} / \mathrm{kg}$ intravenous dosage as a general anesthesia inducer. The animals were left in spontaneous mechanical ventilation with oxygen at $100 \mathrm{vol} \%$, electrocardiographic monitoring and wrist oximetry. Additional propofol doses were used when necessary.

Pentax Gastrofibroscope FG-29P was used with 250W halogen light source and permanent biopsy forceps.

Were collected two samples from the fundus, two from the body and two from the gastric antrum. One sample of each stomach region was immediately immersed in a standard solution for fast urease test. This study considered positive the sample which presented color change until 12 hours (Figure 1 ). The second sample was immersed in a $10 \%$ formol solution for following histopathologic exam stained with Giemsa and modified Giemsa and bacteria identification increased 400x and 1000x.

For each procedure the endoscope equipment was immersed in a $2 \%$ glutaraldehyde solution for a minimum time of 30 minutes after mechanical cleaning with enzymatic solution. The forceps biopsy was treated by autoclave cycles at $134^{\circ} \mathrm{C}$.

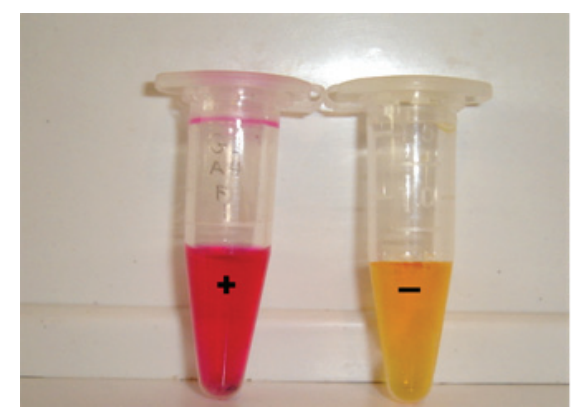

FIGURE 1 - Urease test showing positive and negative sample.

The animals were divided into two 10 positive animal groups: Group I and Group II (Figure 2).

The group II animals were isolated in individual kennels and received therapy at $25 \mathrm{mg} / \mathrm{kg}$ clarithromycin, $50 \mathrm{mg} /$ $\mathrm{kg}$ amoxicillin and $1 \mathrm{mg} / \mathrm{kg}$ lansoprazole (Helicopac ${ }^{\circledR}$ - EMS) every 12 hours during 7 days (Figure 2).

One day after the end of the therapy, the animals were submitted to a new upper digestive endoscopy examination to verify the bacteria eradication. Then, the animals were subdivided 
into two subgroups (experimental and control) composed of five treated animals each (Figure 2).

The experimental group was placed again in contact with group I and the control group was maintained in individual isolation kennels, both during 60 days, when a third upper digestive endoscopy examination was performed followed by Helicobacter spp. search (Figure 2).

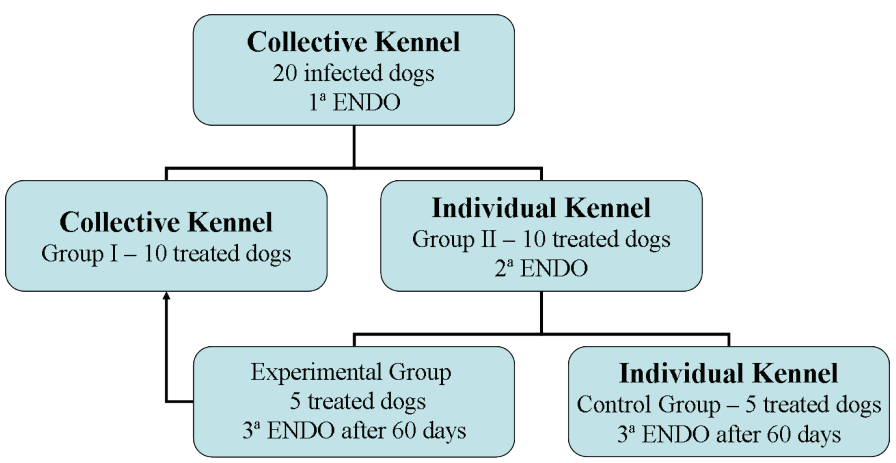

FIGURE 2 - Division of the groups.

Weekly assessment was performed, during all research period. The exception occurred during the seven days medication therapy, when they received daily clinical assessment, within the intention to check possible adverse effects.

The Helicobacter spp. prevalence, its distribution along the gastric mucosa and the triple therapy accuracy were determined by the percentage descriptive analysis. To analyze the reinfection occurrence was performed the Fisher exact test. The Kappa coefficient was utilized at the concordance of the urease test and histopathology.

\section{Results}

In the analyzed samples were seen spiral bacteria in the mucus, over the tissue surface, at the crypt bottom and inside the gastric glands (Figure 3).

The bacteria morphology found was similar in all dogs (Figure 4A). Both experimental group and control group, were seen long spiral bacterias similar to the species Helicobacter heilmannii e Helicobacter bizzozeroni (Figure 4B).
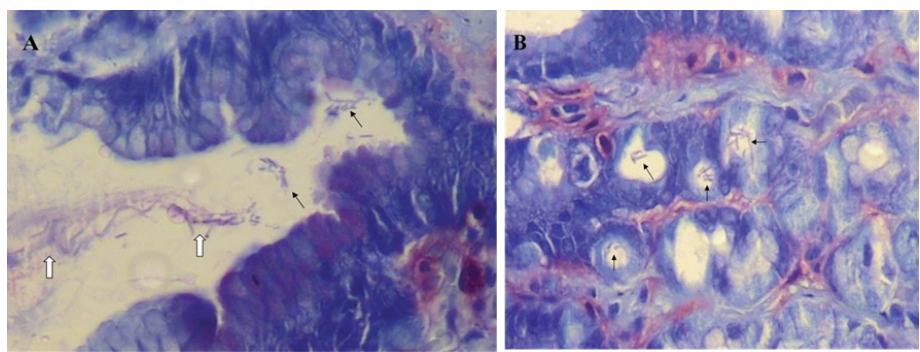

FIGURE 3 - A) Spiral bacterias in the mucus (white arrows), over the tissue surface and at the crypt (black arrows) (Giemsa 400x). B) Spiral bacterias in inside the gastric glands (black arrows) (Giemsa 400x).
According to the urease fast test, the fundus region and the gastric body showed $100 \%$ positivity, whereas the infection at the antrum was $60 \%$. The positivity frequency for histopathologic Helicobacter spp. was $100 \%$ at the fundus, $90 \%$ at the body and only $50 \%$ at the antrum (Figure 5).

After group division, the isolated experimental group analysis resulted in $100 \%$ frequency at the fundus and body, and $80 \%$ at the gastric antrum according to the urease fast test (Figure 6). The histopathology was seen $100 \%$ prevalence at the fundus and $40 \%$ at the antrum (Figure 7 ).
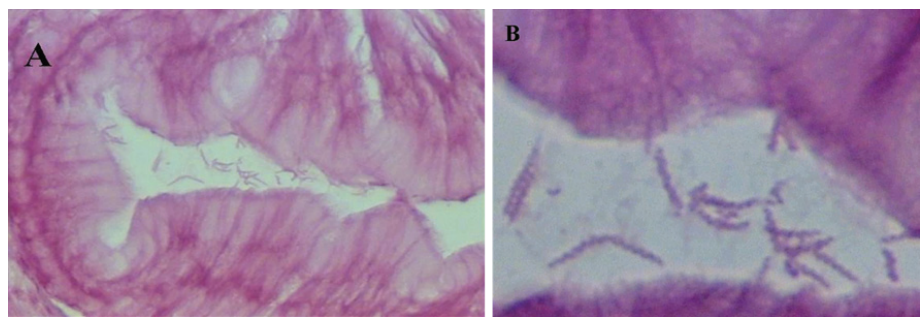

FIGURE 4 - A) First endoscopy: Spiral bacterias at the gastric crypt (modified Giemsa 400x). B) Bacterias with morphological evidence of long spiral (modified Giemsa 1000x).

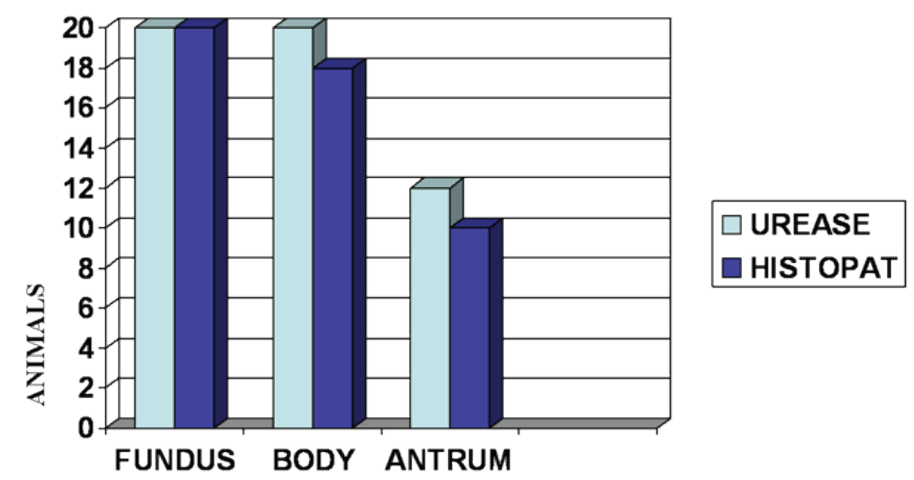

FIGURE 5 - Frequence of Helicobacter $s p$ in the distinct stomach regions at the first endoscopy.

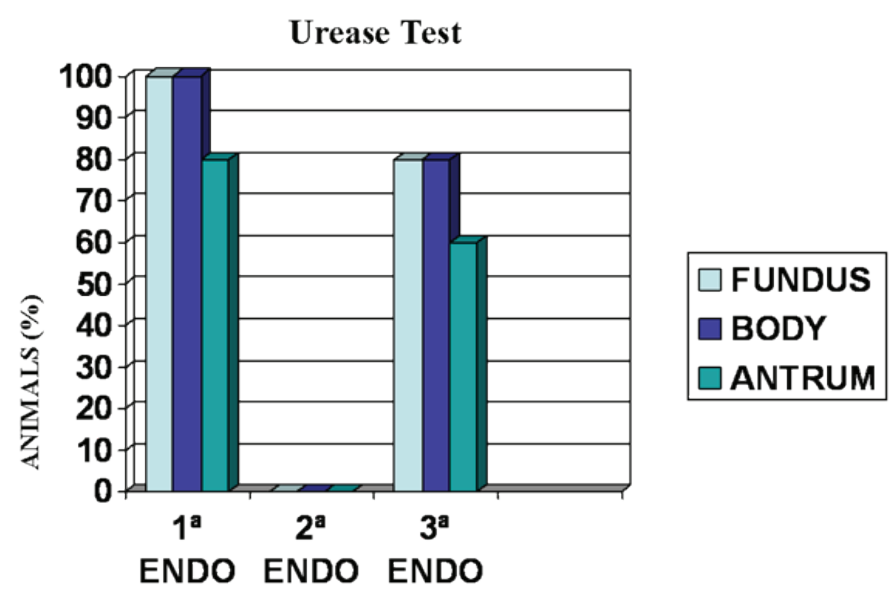

FIGURE 6 - Frequence Helicobacter $s p$ in the distinct stomach regions in the experimental group according to the urease fast test. 


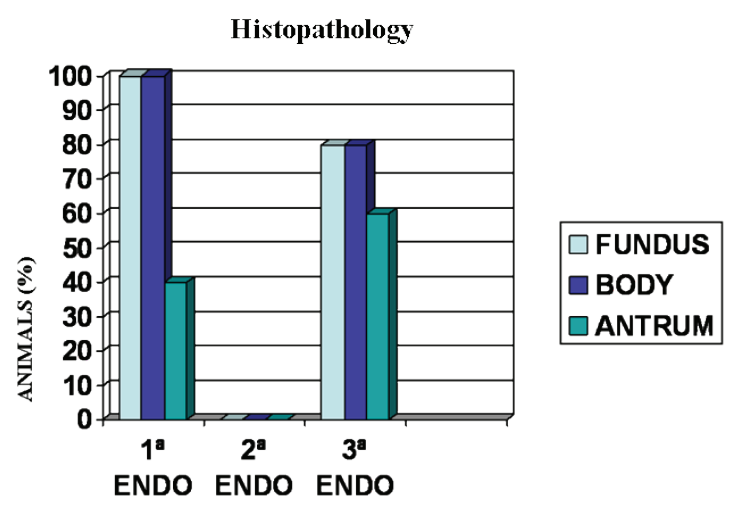

FIGURE 7 - Frequence of Helicobacter $s p$ in the distinct stomach regions in the experimental group according histopathology.

The control group presented $100 \%$ positivity at the fundus and $60 \%$ at the gastric antrum (Figure 8 ). By the histopathology $100 \%$ at the fundus, $80 \%$ at the body and $60 \%$ at the antrum (Figure 9) were positives.

The triple therapy used was efficient in $100 \%$ of the animals after 7 days. The results were negatives at the urease fast tests and histopathologies in both experimental and control groups (Figures 8 and 9). Were not seen Helicobacter spp. at the tissues, at the gastric glands and at the mucus of the biopsied regions (Figure 10).

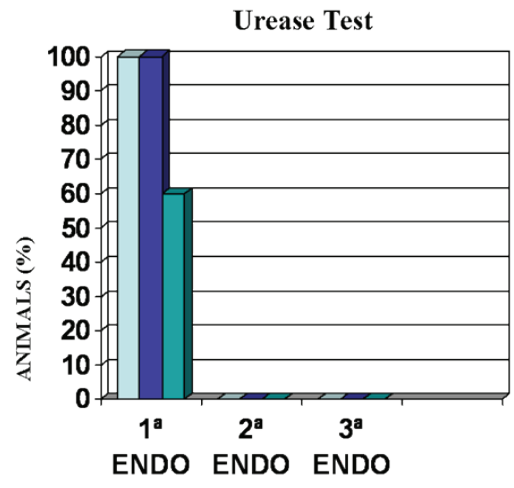

\section{$\square$ FUNDUS $\square$ BODY $\square$ ANTRUM}

FIGURE 8 - Frequence of Helicobacter $s p$ in the distinct stomach regions in the control group according to urease fast test.

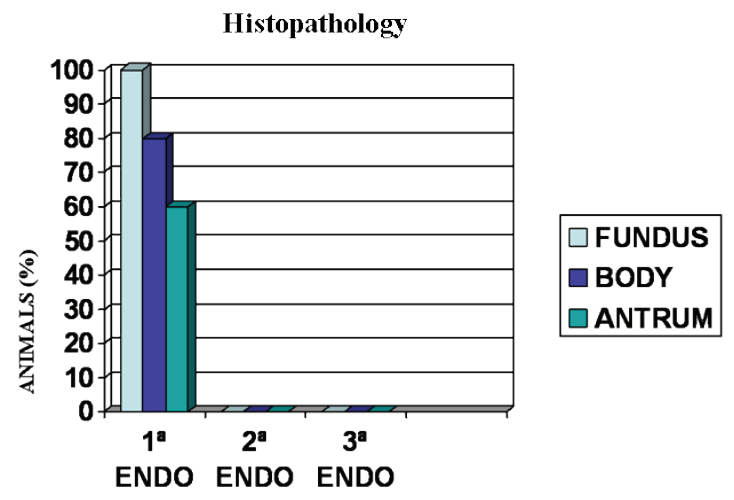

FIGURE 9 - Frequence of Helicobacter $s p$ in the distinct stomach regions in the control group according to the histopathology.
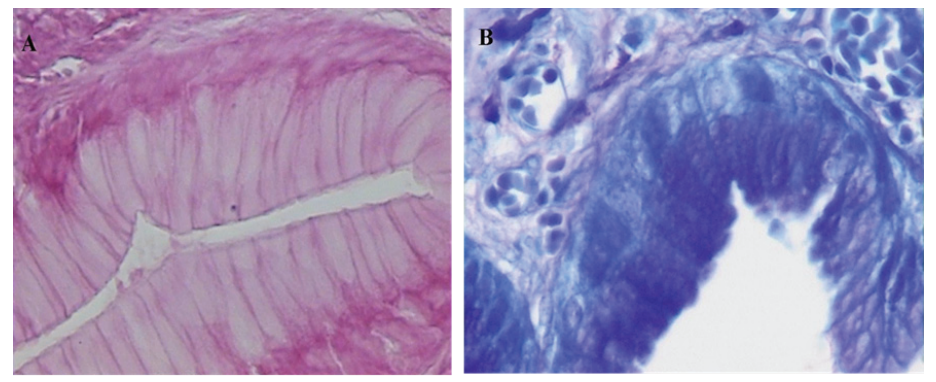

FIGURE 10 - A) Sample of the gastric fundus one day after the end of the triple therapy in control group (modified Giemsa 400x). B) Sample of the gastric fundus one day after the end of the triple therapy in experimental group (Giemsa 400x).

Third digestive endoscopy followed of biopsy 60 days after triple therapy showed that the control group continued eradicated (Figures 8 and 9). The Helicobacter spp. were absent in all samples (Figure 12). At the experimental group, $80 \%$ of the animals showed again Helicobacter spp. presence $(\mathrm{p}<0.05)$. The dogs that had Helicobacter spp. reinfection the fundus and the body showed positive in $100 \%$ of the cases and the antrum in only $50 \%$, according to the urease test (Figure 6). The histopathology identified the bacteria at the crypt bottom (Figure 11A), inside the glands (Figure 11B) and the mucus. The prevalence was $100 \%$ at the fundus and body, and $80 \%$ at the antrum (Figure 7 ).
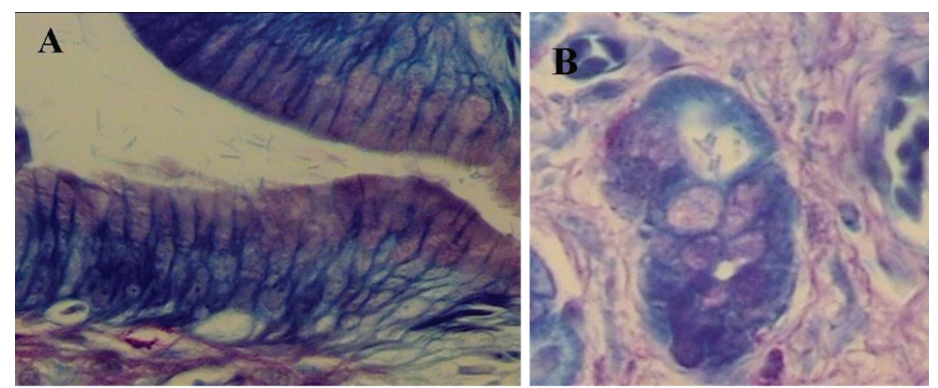

FIGURE 11 - A) Sample of the gastric fundus showing spiral bacterias at the third endoscopy in the experimental group (Giemsa 400x). B) Sample of the gastric fundus showing spiral bacterias inside the glands at the third endoscopy in the experimental group (Giemsa 400x).

Signs of gastrointestinal problems were not observed during the observation period. The possible adverse effects which followed the triple therapy used were not clinically detected.

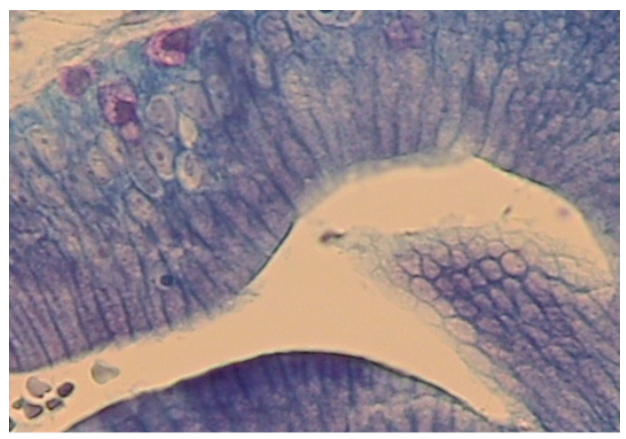

FIGURE 12 - Sample of the gastric fundus without Helicobacter $s p$ in the control group 60 days after the end of the triple therapy (Giemsa 400x). 


\section{Discussion}

Helicobacter spp. are frequently found in $\operatorname{dog} \mathrm{s}^{6-8,15}$, not only in healthy animals ${ }^{15}$, but also in dogs with gastropathy simptoms ${ }^{7}$.

The Helicobacter heilmannii, Helicobacter bizzozeroni, species are morphologically similar bacteria, show spiral evident format and smaller than Helicobacter pylory ${ }^{16,17}$. Helicobacter felis has periplasmatic fibrillations as a particularity ${ }^{18,19}$ and the Helicobacter salomonis are larger microorganisms with discreet wavy morphology ${ }^{20}$.

The Helicobacter spp. were seen in the mucus, over the tissue surface, at the crypt bottom and inside the gastric glands, adding that in this research the bacteria density was higher in areas with more mucus ${ }^{6,7}$.

The bacteria prevalence in street dogs and in dogs which live in crowded areas like, city kennels in Brazil is between $90 \%$ to $100 \%{ }^{6,7,15,21}$. In a retrospective study performed in Colombia shows that the Helicobacter spp. prevalence in pet dogs is $50 \%$ less ${ }^{22}$.

The results found in animals in this study were according to the veterinary literature agreeing to the high prevalence and it is supported by epidemiologic studies with human patients, infected with Helicobacter pylori, which live in collectivity, mainly in groups within a low socioeconomic level and within low hygiene, where it is observed high infection and reinfection average ${ }^{4}$.

Helicobacter pylori is more frequent at the gastric antrum region in humans ${ }^{1}$, however in dogs the fundus and body are presented with high bacteria density and higher probability to find Helicobacter spp. ${ }^{6,7,15,21}$.

The urease fast test can present false negative and false positive results, being the histopathology the most sensible and indispensable technique in detecting gastric helicobacter in dogs. Stained histopathology by Giemsa and modified Giemsa allowed us easy seeing and microorganism identification at the positive urease test. The urease fast test negative result and the tests which the color change time occurred above 2 hours were related to histopathologic exams with helicobacter absence or low colonization density ${ }^{7,21-24}$. This work showed good concordance between the urease test and histopathology according Kappa coefficient.

The fact that the used therapy in this experiment was not followed by adverse effects, was observed using amoxicillin, metronidazole and colloidal bismuth subcitrate ${ }^{25,26}$.

The omeprazole, pantoprazole and lanzoprazole also can act, in vitro, as antimicrobial by inhibiting the bacteria urease $^{21}$. And the lansoprazole seems to have pharmacological power and action time similar to omeprazole, and also present minimal side effects in North America dogs ${ }^{25,26}$.

The therapeutic failure as the cause o major reinfection rate and peptic disease reccurrence or recrudescence was described $^{13,14}$, demonstrating that the triple therapy based in clarithromycin, amoxicillin and lansoprazole reduced in an efficient way the human reinfection cases ${ }^{13}$.

Study with amoxicillin, metronidazole and bismuth subcitrate in dogs with gastropathy clinical signs, positive for
Helicobacter spp, scored clinic status improvement in $80 \%$ of the animals. On this study $57 \%$ of the treated dogs showed again the Helicobacter spp. presence in the gastric mucosa after three years $^{25}$.

According to this research, even with an efficient triple therapy, eradicated individuals can have a higher recurrence probability if maintained intimate contact with positive individuals, associated to low hygiene conditions, specially in crowded situations ${ }^{4}$.

The fecal-oral transmission was suggested at first for the Helicobacter pylori isolation in children diarrhea droppings ${ }^{4}$ meanwhile the microorganism detection in the saliva and dental plaque in infected patients strengthened the oral-oral transmission hypothesis ${ }^{27}$.

Different helicobacter from Helicobacter pylori were also identified at healthy domestic animal oral cavity ${ }^{21,28,29}$.

The Helicobacter pylori transmission among people was related after observing equal microorganism reinfection among married patients ${ }^{30}$.

Literature reviews described in Brazil and abroad state that the natural infection by different bacteria from Helicobacter pylori in human could be a sign of interspecies transmission. These studies suggest, with a lot care, a probable power zoonotic ${ }^{3,21,28,29}$.

This way the canine specie is, in our point of view, a good model to be used on experimental research, focusing on clarify and detail the real transmission mechanism and the bacteria control of this gender, in both animals and human.

\section{Conclusions}

The Helicobacter spp. is found in higher rate at the fundus and gastric body of the dogs. The triple therapy based in clarithromycin, amoxicilin and lansoprazole is an efficient treatment in eradicating Helicobacter spp. in dogs.

The recurrence by Helicobacter spp. occurs in eradicated dogs maintained in contact of 60 days with naturally infected dogs. Crowded situations and the intimate contact with infected dogs determine transmission of Helicobacter spp. in dogs.

\section{References}

1. Ladeira MSP, Salvador DMF, Rodrigues MAM. Biopatologia do Helicobacter pylori. J Bras Patol Med Lab. 2003;39(4):335-42.

2. Marshall BJ, Warren JR. Unidentified curved bacilli in the stomach of patients with gastritis and peptic ulceration. Lancet. 1984;1:13115 .

3. Carvalho GD, Pinto PSA, Vilória MIV, Nero LA. Aspectos 
zoonóticos de Helicobacter spp. Biosci J. 2008;24(4):121-30.

4. Escobar ML, Kawakami E. Evidence of mother-child transmission of Helicobacter pylori infection. Arq Gastroenterol. 2004;41(4):23944.

5. Parente JML, Silva BB, Palha-Dias MPS, Zaterca S, Nishimura NF, Zeitune JMR. Helicobacter pylori infection in children of low and high socioeconomic status in northeastern Brazil. Am Soc Trop Med Hyg. 2006;75(3):509-12.

6. Strauss-Ayali D, Simpson KW. Gastric Helicobacter infeccion in dogs. Vet Clin N Am Small Anim Pract. 1999;29(2): 397-414.

7. Neiger R, Simpson KW. Helicobacter infection in dogs and cats: facts and fiction. J Vet Intern Med. 2000;14(2):125-33.

8. Happonen EU, Saari S, Castren L, Tyni O, Hänninen ML, Westermarck E. Comparison of diagnostic methods for detecting gastric Helicobacter-like organisms in dogs and cats. J Comparat Pathol. 1996;115(2):117-27.

9. Mendall MA, Northfield TC. Transmission of Helicobacter pylori infection. Gut. 1995;37:1-3.

10. Fox JG. Non-human reservoirs of Helicobacter pylori. Aliment Pharmacol Ther. 1995;9(2):93-103.

11. Coelho LGV, Mattos AA, Francisconi CFM, Castro LP, Suraia AB. Efficacy of the dosing regimen of pantoprazole $40 \mathrm{mg}$, amoxicillin $1000 \mathrm{mg}$ and clarithromycin $500 \mathrm{mg}$, twice daily of 7 days, in the eradication of Helicobacter pylori in patients with peptic ulcer. Arq Gastroenterol. 2004;41(1):71-6.

12. Coelho LGV, Zaterca S. Second Brazilian Consensus Conference on Helicobacter pylori infection. Arq Gastroenterol. 2005;42(2):12832.

13. Chether L, Rodrigues Júnior L, Faria CM. Recorrência da infecção por H. pylori na Unifesp. GED. 2005;24(3):121-30.

14. Mesquita MA, Lorena SL, Zeitune JMR, Montes CG, Guerrazzi F, Carvalho Jr AF, Santos JOM, Almeida JRS. Recurrence of Helicobacter pylori infection after eradication therapy in brazilian patients with peptic ulcer. J Clin Gastroenterol. 2005;39(5):447.

15. Moutinho FQ, Thomassian A, Watanabe MJ, Suzano SMC, Sequeira JL. Prevalence of helicobacters and alterations in gastric mucosa of healthy dogs. Arq Bras Med Vet Zootec. 2007;59(4):1080-3.

16. Eaton KA, Dewhirst FE, Paster BJ, Tzellas N, Coleman BE, Paola J, Sherding N. Prevalence and varieties of Helicobacter species in dogs from random sources and pet dogs: animal and public health implications. J Clin Microbiol. 1996;34:3165-70.

17. Hänninen ML, Happonen I, Saari S, Jalava K. Culture and characteristic of Helicobacter bizzozeronii, a new gastric canine Helicobacter sp. Int J Syst Bacteriol. 1996;46(1):160-6. Erratum in: Int J Syst Bacteriol 1996;46(3):839.

18. Lee A, Hazell SL, O'rourke JL, Kouprach S. Isolation of a spiral-shaped bacterium from the cat stomach. Infect Immunol. 1988;56(11):2843-50.
19. Paster BL, Lee A, Fox JG, Dewhirst FE, Tordoff LA, Fraser GJ, O'rouke JL, Taylor NS, Ferrero R. Phylogeny of Helicobacter felis sp. nov., Helicobacter mustelae, and related bacteria. Int J Syst Bacteriol. 1991;41:31-8.

20. Javala K, Kaartinen, M, Utriainen M, Happonen I, Hänninen ML. Helicobacter salomonis sp. nov., a canine gastric Helicobacter sp. Related to H. felis and H. bizzozeronii. Int J Syst Bacteriol. 1997;52:975-80.

21. Takemura LS, Camargo PL, Alfieri AA, Bracarense AP. Helicobacter spp. in cats: association between infecting species and epithelial proliferation within the gastric lamina propria. J Comp Pathol. 2009;141(2-3):127-34.

22. Hernández CA, Gallon G, Restrepo LF. Análises de biópsias gástricas endoscópicas em caninos. Rev Colom Cienc Pecua. 2007;20(3):250-9.

23. Coelho-Neto JS, Andreollo NA, Lopes LR, Nishimura NF, Brandalise NA, Leonardi LS. Late follow-up of gastrectomized patients for peptic ulcer: clinical, endoscopic and histopathological aspects. Arq Gastroenterol. 2005;42(3):146-52.

24. Ferreira LEVVC, Meirelles GSP, Vieira RC, Bragagnolo Jr MA, Chebli JMF, Souza AFM. Changes in ultra rapid urease test and histopathological examination for Helicobacter pylori by antisecretory drugs Arq Gastroenterol. 2001; 38(1):3-8.

25. Happonen EU, Linden J, Westermarck E. Effect of triple therapy on eradication of canine gastric helicobacters and gastric disease. J Small Anim Pract. 2008;41(1):1-6.

26. Leib MS, Duncan RB, Ward DL. Triple antimicrobial therapy and acid suppression in dogs with chronic vomiting and gastric Helicobacter spp. J Vet Intern Med. 2008;21(6):1185-92.

27. Pereira GAS. Detección de Helicobacter pylori en placa dental y en mucosa gástrica de pacientes sometidos a endoscopia digestiva. Acta Odontol Venez. 2005;43(2):113-8.

28. Recordati C, Gualdi V, Tosi S, Facchini RV, Pengo G, Luini M, Simpson KW, Scanziania E. Detection of Helicobacter spp. DNA in the oral cavity of dogs. Vet Microbiol. 2007;119(24):346-51.

29. Souza ML, Kobayasi S, Rodrigues MAM, Hossne ROG, Naresse LE. Prevalence of Helicobacter in canines from animal colony of the State University of Sao Paulo (UNESP)-Botucatu. Acta Cir Bras. 2004;19(5):565-70.

30. Schütze K, Hentschel E, Dragosics B, Hischl AM. Helicobacter pylori reinfection with indentical organisms: transmission by the patients' spouses. Gut. 1995;36:831-3.

\section{Acknowledgement}

To the EMS SIGMA PHRMA S/A which provided the

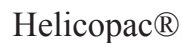

\section{Correspondence:}

Thiago Pires Anacleto

R. João Anny Rey, 232

37130-000 Alfenas - MG Brasil

tpanacleto@gmail.com
Conflict of interest: none Financial source: none

Received: September 23, 2010

Review: November 18, 2010

Accepted: December 21, 2010 